\title{
Change of physicochemical properties, phytochemical contents and biological activities during the vinegar fermentation of Elaeagnus multiflora fruit
}

\author{
Kye Man Cho, Chung Eun Hwang, Ok Soo Joo* \\ Department of Food Science, Gyeongnam National University of Science and Technology, Jinju 52725, Korea
}

\section{보리수 열매 식초 발효 중 이화학적 특성, phytochemical 함량 및 생리활성 변화}

\author{
조계만 · 황정은 · 주옥수* \\ 경남과학기술대학교 식품과학부
}

\begin{abstract}
This study evaluated the changes of physiochemical properties, phytochemical contents, and biological activities during the vinegar fermentation of Elaeagnus multiflora fruit. The contents of $\mathrm{pH}$ and reducing sugar decreased from 3.55 and $6.88 \mathrm{mg} / \mathrm{mL} 3.34$ and $2.13 \mathrm{mg} / \mathrm{mL}$, respectively. However the acidity increased from $0.48 \%$ to $5.48 \%$ during the vinegar fermentation. The alcohol contents increased up to a maximum value of $6.6 \%$ at 20 days, and it then decreased at the end fermentation days $(\mathbf{2 . 0 \%})$. The viable numbers of acetic acid bacteria and yeasts increased from $4.32 \log \mathrm{CFU} / \mathrm{mL}$ and $3.23 \log \mathrm{CFU} / \mathrm{mL}$ at 10 days to $5.4 \log \mathrm{CFU} / \mathrm{mL}$ and $5.5 \log \mathrm{CFU} / \mathrm{mL}$ during the spontaneous fermentation, respectively. The major organic acids were acetic acid $(38.84 \mathrm{mg} / \mathrm{mL})$, lactic acid $(4.92 \mathrm{mg} / \mathrm{mL})$, and malic acid $(1.51 \mathrm{mg} / \mathrm{mL})$. The soluble phenolic and flavonoid contents increased from $0.79 \mathrm{mg} / \mathrm{mL}$ and $0.12 \mathrm{mg} / \mathrm{mL}$ of initial fermentation day to $1.22 \mathrm{mg} / \mathrm{mL}$ and $0.14 \mathrm{mg} / \mathrm{mL}$ during the spontaneous fermentation. Content of epicatechin gallate decreased from $168.1 \mu \mathrm{g} / \mathrm{mL}$ at 10 days to $115.97 \mu \mathrm{g} / \mathrm{mL}$. However the content of gallic acid increased from $18.52 \mu \mathrm{g} / \mathrm{mL}$ to $95.07 \mu \mathrm{g} / \mathrm{mL}$ during fermentation. After 60 days of the fermentation, the antioxidant and digestive enzyme inhibitory activities were $\mathbf{7 1 . 3 5 \%}$ (DPPH), 79.27\% (ABTS), $68.72 \%(\cdot \mathrm{OH}), \mathbf{8 5 . 4 2} \%$ (a-glucosidase), $52.12 \%$ (a-amylase), and 53.66\% (pancreatic lipase), respectively.
\end{abstract}

Key words : Elaeagnus multiflora, vinegar, flavonols, phenolic acids, a-glucosidase inhibition activity

\section{서 론}

뜰보리수(Elaeagnus multiflora)는 보리수나무과(Elaeagnaceae) 에 속하는 식물로 알려져 있으며 뜰보리수 열매는 단맛을 가지고 있어 식용이 가능하지만 떫은맛 때문에 주로 관상용 또는 과수로 재배되어 왔다(1). 일본이 원산지인 이 열매는 한방에서 혈액 순환, 소화불량, 부종, 생리통 개선 등에 사용

*Corresponding author. E-mail : osjoo@gntech.ac.kr Phone : 82-55-751-3273, Fax : 82-55-751-3279

Received 6 December 2016; Revised 6 February 2017; Accepted 8 February 2017

Copyright (c) The Korean Society of Food Preservation. All rights reserved.
을 하고 있다 $(2,3)$. 일반적으로 식물체는 자동산화로부터 자신을 방어하기 위하여 다양한 phytochemicals의 polyphenol 성 화합물을 함유하고 있다. 보리수 열매 역시 gallic acid, catechin, epicatechin, epigallocatechin, catechin gallate, epicatechin gallate 및 epigallocatehin gallate 등과 같은 polyphenol성 화합물이 함유되어 있어 free 라디칼 소거능 및 a-glucosidase 저해 활성 등이 있는 것으로 보고되어 있다 $(1,4,5)$

식초는 자연이 준 기적의 발효식품으로 예부터 중요한 조미료로 사용되어 왔으며 제조법에 따라 합성식초와 양조 식초로 나뉘게 된다. 인간이 만들어 낸 발효 식품 중 하나이 며 전분이 알코올 발효를 거쳐 술이 되고 이어서 초산 발효 로 생성된 초산을 주성분으로 함유하는 발효 식품이다(6) 
국내의 식초 산업은 1970 년대에 빙초산을 희석하여 만든 저가의 합성식초가 주를 이루고 있었고 80년대에는 주정과 과즙 등을 첨가한 양조식초의 소비가 급증하였다(7). 90년 대 이후에 들어서면서부터 $100 \%$ 과실을 사용한 양조식초 의 생산이 시작되었으며(7), 딸기(8), 참다래(9), 감(10), 사 과(11), 복분자(7) 등이 있다. 이러한 식초는 다양한 발효 기질에 따라 유기산, 유리당, 각종 아미노산들을 함유하고 있어 체지방 감소와 성인병 예방에 탁월한 것으로 보고되어 있다(12).

따라서 본 연구에서는 식품학적 가치는 충분히 있으나 주로 관상용이나 한방치료에만 국한되는 뜰보리수 열매의 이용성을 증대시키기 위한 일환으로 뜰보리수 열매의 자연 식초 발효 중 이화학적 특성 및 효능평가와 더불어 발효기 간에 따른 기능성 화합물들의 함량 변화와 연관성을 살펴보 았다.

\section{재료 및 방법}

\section{재료 및 시약, 균주}

보리수 열매 식초는 경상남도 거제시 남부면 소재 수림 농장에서 담금한 후 10 일이 경과한 시료를 60 일간 채취하 여 사용하였다. 본 실험에 사용한 미생물 배양용 배지는 Difco사 제품(USA)을 사용하였다. 12 개 표준 phenolic acid 화합물 (gallic acid, p-hydroxylbenzoic acid, protocatechuic acid, vanillic acid, p-coumraic acid, caffeic acid, ferulic acid, tannic acid, salicylic acid, trans-cimmamic acid 및 chlorogenic acid) 및 3 개 표준 flavanol 화합물(rutin, qucercetin 및 kaempferol), 7개의 flavan-3-ol 표준 화합물(catechin, epicatechin, epigallocatechin, catechin gallate, epicatechin gallate, gallocatechin gallate, 및 epigallocatechin gallate)은 Sigma Chemical Co.(St. Louis, MO, USA)에서 구입하였다. 10 개 표준 유기산 화합물(oxalic acid, tartaric acid, malic acid, ascorbic acid, acetic acid, maleic acid, citric acid, succinic acid, fumaric acid, glutaric acid) 역시 Sigma Chemical Co. 에서 구입하였다. HPLC-grade $\mathrm{H}_{2} \mathrm{O}$, methanol, acetonitrile 그리고 glacial acetic acid는 Fisher Scientific (Fairlawn, NJ, USA)에서 구입하였다. Folin-Cicalteu phenol, 2,2-diphenyl-1-picrylhydrazyl(DPPH), potassium ferricyanide, trichloroacetic acid(TCA), 2,2'-Azino-bis(3ethylbenzothiazoline-6-sulfonic acid) diammonium salt(ABTs), 2,4,6tri(2-pyridyl)-1,3,5-triazine(TPIZ), p-nitrophenol- a-D-glucopyranoside (p-NPG), p-nitrophenol-butyrate(p-NPB) a-glucosidase(Type I: from Bakers Yeast), a-amylase(Human saliva), lipase(Type II: porcine pancreas)또한 Sigma Chemical Co.에서 구입하 였다.
$\mathrm{pH}$ 와 산도

$\mathrm{pH}$ 는 $\mathrm{pH}$ meter(MP $220 \mathrm{pH}$ meter, U.K)를 사용하여 측정 하였다. 산도는 보리수 열매 식초 발효액 $10 \mathrm{~mL}$ 에 대해서 $0.1 \mathrm{~N}-\mathrm{NaOH}$ 로 $\mathrm{pH}$ 8.3까지 중화시킨 후 아래의 식을 통하여 초산의 양으로 환산하였다.

\section{산도 $(\%$, as Acidity acetic acid $)=0.006 \times \mathrm{mL}$ of $0.1 \mathrm{~N}$} $\mathrm{NaOH} \times \mathrm{F} \times 100 /$ Sample $(\mathrm{mL})$

\section{환원당 및 알코올 함량}

환원 당은 Miller의 DNS법(13)을 사용하여 분석하였다. 식초 발효액을 원심분리기로 원심분리한 후 상등액을 3 차 증류수로 50 배 희석한 후 시료 $0.1 \mathrm{~mL}$ 에 DNS 시약을 1 $\mathrm{mL}$ 첨가하여 $100^{\circ} \mathrm{C}$ 의 끓는 물에서 10 분 동안 발색시킨 후 얼음물에서 급속히 냉각하여 분광광도계(Spectronic 2D, $\mathrm{USA}$ )를 사용하여 $570 \mathrm{~nm}$ 에서 흡광도를 측정하여 검량선 과 비교하였다. 검량선 작성을 위한 표준물질로는 포도당 을 사용하였다.

알코올 측정은 증류법으로 발효 중에 있는 시료 $100 \mathrm{~mL}$ 에 물 $100 \mathrm{~mL}$ 를 가하여 희석시킨 후 증류시켜 $80 \mathrm{~mL}$ 을 회수한 후 증류수 $20 \mathrm{~mL}$ 를 넣어 $100 \mathrm{~mL}$ 로 표선을 맞춘 다음 알코올계로 측정하였다.

\section{생균수 확인}

보리수 열매 식초 발효 중의 초산균수 측정은 발효액을 멸균증류수로 10 배 희석하고 yeast extract( $1 \%), \mathrm{CaCO}_{2}$ (4\%), ethanol(1.5\%)이 함유된 YCE 한천배지에 도말한 후 $30^{\circ} \mathrm{C}$ 에서 72 시간 동안 배양한 후 clear zone이 형성된 집락 을 계수하여 초산균수를 측정하였다. 효모균수 측정은 발 효액을 멸균증류수로 10 단 희석법으로 적당히 희석하고 potato dextrose 한천배지(PDA)에 chlorophenicol $100 \mu \mathrm{g} / \mathrm{mL}$ 이 함유된 배지에 speared plate method로 도말한 후 $30^{\circ} \mathrm{C}$ 에 서 72 시간 동안 배양하여 형성된 집락을 계수하여 효모균 수를 측정하였다.

\section{유기산 분석}

유기산 분석은 TSKgel ODS-100V column $(4.6 \times 250 \mathrm{~mm}$, $5 \mu \mathrm{m}$, Tosoh Corp., Tokyo, Japan)과 HPLC(Agilent 1200 series, Agilent Co., Forest Hill, Australia)을 이용하여 분석되 었다. $0.1 \%$ phosphoric acid를 이용하여 30 분 수행하였고 $40^{\circ} \mathrm{C}$ 에서 $1 \mathrm{~mL} / \mathrm{min}$ 의 흐름을 적용하였다. 시료는 $20 \mu \mathrm{L}$ 를 주입하였고 UV 검출기(Agilent 1200 series, Agilent Co.) $210 \mathrm{~nm}$ 에서 측정하였다.

\section{수용성 phenolics 함량 측정}

수용성 phenolics는 Folin-Ciocalteu법(14)으로 측정하였 다. 각각의 식초 발효액을 원심분리기로 원심분리한 상등 
액을 50 배 혹은 100 배 희석한 후 $0.5 \mathrm{~mL}$ 를 시험관에 분주하 고 $25 \% \mathrm{Na}_{2} \mathrm{CO}_{3}$ 용액 $0.5 \mathrm{~mL}$ 를 첨가하여 3분간 정치시켰다. 다시 $2 \mathrm{~N}$-Folin-Ciocalteu phenol 시약 $0.25 \mathrm{~mL}$ 를 첨가하여 혼합한 다음 상온에서 1 시간 동안 정치시켜 발색시켰다. 발색된 청색을 분광광도계(Spectronic 2D)를 이용하여 750 $\mathrm{nm}$ 에서 흡광도를 측정하였다. 이때 총 phenolics 함량은 gallic acid를 이용하여 작성한 표준곡선으로부터 함량을 구하였다. Gallic acid를 이용한 표준곡선은 gallic acid의 최종농도가 $0,25,50100 \mathrm{mg} / \mathrm{L}$ 가 되도록 하여 위와 같은 방법으로 $750 \mathrm{~nm}$ 에서 흡광도를 측정하여 작성하였다. 각 실험은 3 회 반복하여 수행하였다.

\section{수용성 flavonoids 함량 측정}

수용성 flavonoids는 Lee 등(5)의 방법과 동일하게 측정하 였다. 즉 각각의 식초 발효액을 원심분리기로 원심분리한 상등액 $0.5 \mathrm{~mL}$ 를 시험관에 취하고 여기에 diethylene glycol $1.0 \mathrm{~mL}$ 및 $1 \mathrm{~N} \mathrm{NaOH} 0.01 \mathrm{~mL}$ 를 가하여 $37^{\circ} \mathrm{C}$ 에서 1 시간 반응시켰다. 그 후 분광광도계(Spectronic 2D)를 이용하여 $420 \mathrm{~nm}$ 에서 흡광도를 측정하였다. 이때 표준물질은 rutin을 이용하여 작성한 표준 검량곡선으로부터 값을 산출하였다.

\section{Flavanols 분석}

Flavanol 분석은 TSKgel ODS- $100 \mathrm{Z}$ column $(4.6 \times 250 \mathrm{~mm}$, $5 \mu \mathrm{m}$, Tosoh Corp. Tokyo, Japan)과 HPLC(Agilent 1200 series, Agilent Co.)을 이용하여 분석되었다. 10 에서 $100 \%$ B linear gradient로 $0.5 \%$ acetic $\operatorname{acid}(\mathrm{pH} 2.5)$ (solution A) 와 $100 \%$ Acetinitrile(solution B)을 이용하여 30분 수행되었고 $30^{\circ} \mathrm{C}$ 에서 $1 \mathrm{~mL} / \mathrm{min}$ 의 흐름을 적용되었다. 시료 $20 \mu \mathrm{L}$ 를 주입하였고 UV 검출기(Agilent 1200 series, Agilent Co.)의 $270 \mathrm{~nm}$ 에서 측정하였다(1).

\section{Phenolic acids 분석}

Phenolic acid 분석은 XTerra ${ }^{\mathrm{TM}} \mathrm{RP}$ C8 column $(4.6 \times 250$ $\mathrm{mm}, 5 \mu \mathrm{m}$, Waters Corp. Milford, MA, USA)과 HPLC(Agilent 1200 series, Agilent Co.)을 이용하여 분석되었다. 0.5\% glacial acetic acid(solution A)와 $100 \%$ 메탄올(solution B)로 40 분으로 $60-100 \%$ linear gradient한 것은 $30^{\circ} \mathrm{C}$ 에서 1 $\mathrm{mL} / \mathrm{min}$ 의 흐름률을 적용하였다. 시료는 $20 \mu \mathrm{L}$ 로 주입하였 고 UV 검출기(Agilent 1200 series, Agilent Co.)의 $280 \mathrm{~nm}$ 에 서 측정하였다(1).

\section{$\mathrm{DPPH}$ 라디칼 소거 활성}

Lee 등(5)의 방법을 따라 라디칼 소거활성을 측정하였다. $1.5 \times 10^{-4} \mathrm{M} \mathrm{DPPH}$ (1,1-diphenyl-2-picryhdrazyl) 용액 $0.8 \mathrm{~mL}$ 와 각각의 식초 발효액을 원심분리기로 원심분리한 상등액 $0.2 \mathrm{~mL}$ 를 가한 후 10 초간 vortex하고 실온에서 30 분 방치한 후 분광광도계(Spectronic 2D)를 이용하여 $525 \mathrm{~nm}$ 에서 흡
광도를 측정하였다. 각 실험은 3회 반복하여 수행하였다. 음성 대조구 실험은 시료 대신에 증류수를 $0.2 \mathrm{~mL}$ 를 취하여 실험하였다. DPPH 라디칼 소거활성은 실험구와 음성 대조 구의 흡광도를 구하여 아래와 같이 백분율(\%)로 표시하 였다.

$\mathrm{DPPH}$ 라디칼 소거 활성(\%)=[1-(실험구의 흡광도/음성 대조구의 흡광도)] $\times 100$

\section{ABTS 라디칼 소거 활성}

$7 \mathrm{mM}$ ABTS 용액과 $2.45 \mathrm{mM} \mathrm{K} \mathrm{S}_{2} \mathrm{O}_{8}$ 을 1:1로 섞고, 암실 에서 12 16시간 보관하여 $\mathrm{ABTS}$ radical(ABTS ${ }^{+}$)을 생성시 켰다. ABTS radical(ABTS ${ }^{+}$)은 $732 \mathrm{~nm}$ 에서 흡광도값이 $0.7 \pm 0.02$ 가 되도록 에탄올로 희석하여 사용하였다. 에탄올 로 희석된 $\mathrm{ABTS}$ 용액(흡광도 $0.7 \pm 0.02$ ) $0.9 \mathrm{~mL}$ 과 각각의 식초 발효액을 원심분리기로 원심분리한 상등액 $0.1 \mathrm{~mL}$ 를 섞고, 정확히 3 분 후 분광광도계(Spectronic $2 \mathrm{D}$ )를 이용하여 $732 \mathrm{~nm}$ 에서 흡광도를 측정하였다(5). ABTS cation(ABTS ${ }^{+}$) 라디칼 소거활성은 실험구와 음성 대조구의 흡광도를 구하 여 아래와 같이 백분율(\%)로 표시하였다.

$\mathrm{ABTS}$ 라디칼 소거 활성 $(\%)=1-[($ 실험구의 흡광도/음성 대조구의 흡광도)] $\times 100$

\section{Hydroxyl $(\cdot \mathrm{OH})$ 라디칼 소거활성}

각각의 식초 발효액을 원심분리기로 원심분리한 상등액 을 분석시료로 준비하였다. hydroxyl 라디칼 소거능은 10 mM FeSO 4 -7H20-EDTA $0.2 \mathrm{~mL}, 10 \mathrm{mM}$ 2-deoxyribose 0.2 $\mathrm{mL}, 10 \mathrm{mM} \mathrm{H}_{2} \mathrm{O}_{2} 0.2 \mathrm{~mL}$ 및 식초 시료액 $1.4 \mathrm{~mL}$ 를 혼합하고 $37^{\circ} \mathrm{C}$ 에서 4 시간 동안 반응시켰다. 이 혼합액에 $1 \%$ thiobarbituric acid와 $2.8 \%$ trichloroacetic acid를 각각 $1 \mathrm{~mL}$ 를 가하여 $100^{\circ} \mathrm{C}$ 에서 20 분간 가열하여 발색후 냉각시키고 $520 \mathrm{~nm}$ 에서 흡광도를 측정하였다(15). 음성 대조구 실험은 시료 대신에 완충액을 사용하였고, 라디칼 소거능은 시료 용액의 첨가구와 무첨가구 사이의 흡광도의 차이를 백분율 (\%)로 나타내었다.

Hydroxyl 라디칼 소거 활성 $(\%)=1-[($ 실험구의 흡광되음성 대조구의 흡광도) $\times 100$

\section{a-Glucosidase 저해 활성}

각각의 식초 발효액을 원심분리한 상등액 $50 \mu \mathrm{L}, 0.5$ $\mathrm{U} / \mathrm{mL}$ a-glucosidase 효소액 $50 \mu \mathrm{L}$ 및 $200 \mathrm{mM}$ sodium phosphate buffer(pH 6.8) $50 \mu \mathrm{L}$ 와 혼합하여 $37^{\circ} \mathrm{C}$ 에서 10 분 간 반응 후 sodium phosphate buffer(pH 6.8)에 $5 \mathrm{mM} \mathrm{p-NPG}$ 을 $100 \mu \mathrm{L}$ 가하여 $37^{\circ} \mathrm{C}$ 에서 10 분간 반응시켰다. 반응액에 $100 \mathrm{mM} \mathrm{Na} \mathrm{CO}_{3} 750 \mu \mathrm{L}$ 로 반응을 정지시키고 $420 \mathrm{~nm}$ 에서 
흡광도를 측정하고 저해율을 계산하였다. 음성 대조구로 완충액을 사용하였다(15). 각 실험은 3 회 반복하여 수행하 였다.

$a-G l u c o s i d a s e$ 저해 활성 $(\%)=1-[($ 실험구의 흡광도/음성 대조구의 흡광도)] $\times 100$

\section{a-Amylase 저해 활성}

각각의 식초 발효액을 원심분리한 상등액 $50 \mu \mathrm{L}$ 을 시험 관에 분주한 후 a-amylase $(1.0 \mathrm{U} / \mathrm{mL})$ 효소 용액 $50 \mu \mathrm{L}$ 와 $200 \mathrm{mM}$ sodium phosphate buffer(pH 6.8) $50 \mu \mathrm{L}$ 를 첨가하여 $37^{\circ} \mathrm{C}$ 에서 10 분간 예비 반응을 시켰다. 이 반응액에 $200 \mathrm{mM}$ sodium phosphate buffer(pH 6.8) 에 녹인 $1 \%$ 전분 용액을 $0.25 \mathrm{~mL}$ 를 가하여 다시 $37^{\circ} \mathrm{C}$ 에서 10 분간 반응 시켰다. 이후 에는 $0.5 \mathrm{~N} \mathrm{NaOH}$ 및 $30 \%$ 타르타르산나트륨칼륨을 용해한 $48 \mathrm{mM}$ DNS 시약을 $0.25 \mathrm{~mL}$ 첨가하여 $100^{\circ} \mathrm{C}$ 에서 20 분간 끓여 발색시킨 후 바로 냉각시키고 $570 \mathrm{~nm}$ 에서 흡광도를 측정하였다(16). 모든 효소 저해 활성의 음성 대조구는 시료 대신에 완충액을 취하였으며 시료용액의 첨가구와 무첨가 구 사이의 흡광도 차이를 백분율(\%)로 나타내었다.

a-Amylase 저해 활성 $(\%)=1-[($ 실험구의 흡광되음성 대조 구의 흡광도) $] \times 100$

\section{Pancreatic lipase 저해 활성}

Pancreatic lipase 저해 활성은 각각의 식초 발효액을 원심 분리한 상등액 $50 \mu \mathrm{L}$, pancreatic lipase $(1.0 \mathrm{U} / \mathrm{mL})$ 효소 용액 $50 \mu \mathrm{L}$ 및 $200 \mathrm{mM}$ sodium phosphate buffer(pH 6.8) $50 \mu \mathrm{L}$ 를 혼합하여 $37^{\circ} \mathrm{C}$ 에서 10 분간 예비 반응시켰다. 반응 후 sodium phosphate buffer(pH 6.8)에 녹인 $5 \mathrm{mM}$ p-nitrophenolbutyrate(p-NPB) $100 \mu \mathrm{L}$ 를 가하여 동일하게 10 분간 반응시 킨 후 $100 \mathrm{mM} \mathrm{Na}_{2} \mathrm{CO}_{3} 0.75 \mathrm{~mL}$ 를 가해 반응을 종결시켜 $420 \mathrm{~nm}$ 에서 흡광도를 측정하였다(17). 모든 효소 저해 활성 의 음성 대조구는 시료 대신에 완충액을 취하였으며 시료용 액의 첨가구와 무첨가구 사이의 흡광도 차이를 백분율(\%) 로 나타내었다.

Pancreatic lipase 저해 활성 $(\%)=1-[($ 실험구의 흡광되음성 대조구의 흡광도) $] \times 100$

\section{결과 및 고찰}

\section{뜰보리수 열매의 식초 자연 발효 중 이화학적 특성 및 생 균수 변화}

뜰보리수 열매 식초의 발효 기간별 이화학적 특성 변화 는 Table 1 과 같았다. 발효 10 일째 $\mathrm{pH}$ 는 3.55 수준이었고
발효 20 일째에는 3.44 로 측정되었다. 발효 40 일째에는 이보 다 약간 더 감소하여 3.36이었고 발효 60일째 3.34로 발효가 진행됨에 따라 조금씩 감소하는 경향을 보였다. 산도는 발 효 10 일째 $0.48 \%$ 로 나타났고 발효 20 일째 $1.92 \%$ 를 나타내 었고 발효 40 일째 급격히 증가하였고 발효 60 일째 $5.48 \%$ 로 크게 증가하였다. 환원당은 발효 10 일째 $6.88 \mathrm{mg} / \mathrm{mL}$ 를 함 유하고 있었고 발효 과정 중 서서히 감소하여 발효 40 일째 에는 $2.13 \mathrm{mg} / \mathrm{mL}$ 를 함유하고 있었다. 알코올은 발효 10 일 째 $2.6 \%$ 로 나타났으며 발효 20 일째 $7.6 \%$ 로 가장 높았다. 알코올 함량은 발효 10 일째 $2.6 \%$ 에서 20 일째까지 증가하 여 $6.6 \%$ 로 최대치를 나타내었고, 이후 감소하여 발효 60 일 째 $2.0 \%$ 로 나타났다(Table 1).

Table 1. Change of $\mathrm{pH}$, acidity, reducing sugar, and alcohol contents during the vinegar fermentation of Elaeagnus multiflora fruit

\begin{tabular}{ccccc}
\hline \multirow{2}{*}{ Indexes } & \multicolumn{4}{c}{ Fermentation time (day) } \\
\cline { 2 - 5 } & 10 & 20 & 40 & 60 \\
\hline $\mathrm{pH}$ & $3.55 \pm 0.02^{1)}$ & $3.44 \pm 0.01$ & $3.36 \pm 0.01$ & $3.34 \pm 0.01$ \\
Acidity (\%, v/v) & $0.48 \pm 0.01$ & $1.92 \pm 0.03$ & $3.78 \pm 0.02$ & $5.48 \pm 0.02$ \\
Reducing sugar (mg/mL) & $6.88 \pm 0.04$ & $3.30 \pm 0.02$ & $2.42 \pm 0.01$ & $2.13 \pm 0.02$ \\
Alcohol (\%, v/v) & $2.6 \pm 0.02$ & $7.6 \pm 0.03$ & $6.8 \pm 0.04$ & $4.0 \pm 0.02$ \\
\hline
\end{tabular}

${ }^{11}$ All data are presented as the mean \pm SD of triplicate determinations.

뜰보리수 열매 식초의 자연 발효 중 초산균수와 효모균 수 변화는 Table 2 와 같았다. 초산균수는 발효 10 일째 4.32 $\log \mathrm{CFU} / \mathrm{mL}$ 에서 증가하여 발효 60일째 $5.4 \log \mathrm{CFU} / \mathrm{mL}$ 있었고, 효모균수는 발효 10 일째 $3.23 \log \mathrm{CFU} / \mathrm{mL}$ 에서 증 가하여 발효 40일째 $5.8 \log \mathrm{CFU} / \mathrm{mL}$ 로 최대치를 나타낸 후 발효 60 일째에는 $5.5 \log \mathrm{CFU} / \mathrm{mL}$ 로 감소하였다(Table 2).

일반적으로 식초 발효 시 초산균수가 증가함에 따라 $\mathrm{pH}$, 환원당 그리고 알코올 함량이 감소하는 것은 초산 발효의 전형적인 결과라 할 수 있다(18). 또한 발효가 진행되면서 초산균이 생성한 초산(acetic acid) 등의 유기산에 의해 산도 는 증가하게 되며 $(7,8)$ 이는 본 연구 결과와도 일치하였다. 한편 본 연구에서는 발효 20 일째 알코올 함량 $(6.6 \%)$ 이 가장 높게 나타났고 이는 Table 2에 나타낸바와 같이 발효 20일 째 효모의 생균수(5.15 $\log \mathrm{CFU} / \mathrm{mL})$ 가 초산균 생균수(5.11 $\log \mathrm{CFU} / \mathrm{mL}$ )보다 약간 더 많은 것으로 나타나 초산발효와

Table 2. Change of the viable cell numbers during vinegar fermentation of Elaeagnus multiflora fruit

\begin{tabular}{ccccc}
\hline \multirow{2}{*}{$\begin{array}{c}\text { Viable cell numbers } \\
(\log \text { CFU/mL) }\end{array}$} & 10 & 20 & 40 & 60 \\
\cline { 2 - 5 } & \multicolumn{4}{c}{ Fermentation time (day) } \\
\hline Acetic acid bacteria & $4.32 \pm 0.02^{1)}$ & $5.11 \pm 0.26$ & $5.4 \pm 27$ & $5.4 \pm 0.27$ \\
Yeast & $3.23 \pm 0.16$ & $5.15 \pm 0.26$ & $5.8 \pm 0.29$ & $5.5 \pm 0.28$ \\
\hline
\end{tabular}

${ }^{11}$ All data are presented as the mean $\pm \mathrm{SD}$ of triplicate determinations. 
알코올 발효가 동시에 진행된 것으로 추정하였다. 발효 40 일째에는 초산균보다는 효모 생균수가 좀 더 많았으나 발효 60 일째에는 효모의 경우 감소하는 추세를 나타내 사멸기로 들어섰고 초산균은 정지기에 들어선 것으로 추정되었다.

\section{뜰보리수 식초 자연 발효 중 유기산 함량 변화}

뜰보리수 열매 식초의 발효 기간별 유기산 함량 변화를 살펴본 결과 Table 3 과 같았다. 발효 10 일부터 60 일까지의 주요 유기산은 acetic acid와 lactic acid의 함량이 가장 높았 으며, glutaric aid는 발효 과정 중 검출되지 않았다. Oxalic acid는 발효 40 일까지 $0.15 \mathrm{mg} / \mathrm{mL}$ 로 큰 변화가 없었으나 발효 60 일째 $0.26 \mathrm{mg} / \mathrm{mL}$ 로 약간 증가하였다. Tartaric acid 는 발효 40 일까지 조금씩 감소하다가 발효 60 일째 약간 증가하여 $0.93 \mathrm{mg} / \mathrm{mL}$ 를 함유하고 있었다. 한편 유기산 중 가장 크게 증가한 acetic acid는 발효 10 일째 $2.64 \mathrm{mg} / \mathrm{mL}$ 수준에 불과하였으나 발효가 진행됨에 따라 각각 16.35 $\mathrm{mg} / \mathrm{mL}$ (발효 20일), $18.31 \mathrm{mg} / \mathrm{mL}$ (발효 40일) 및 38.84 $\mathrm{mg} / \mathrm{mL}$ (발효 60일)를 함유하고 있었다. 이 외 malic acid, lactic acid, citric acid는 발효가 진행됨에 따라 조금씩 증가 하는 경향을 나타내었고 fumaric acid는 발효 40일까지 증가 하다 60 일째 약간 감소하였다.

식초 발효에 있어서 풍미 향상에 도움이 된다고 알려져 있는 호박산(succinic acid)은 발효 과정 중 조금씩 증가하여 발효 60일째 $2.25 \mathrm{mg} / \mathrm{mL}$ 를 함유하고 있었다(19). 한편 복분 자 식초(7), 참다래 식초(9), 흑마늘 식초(19) 및 제주감귤 식초(20)의 연구에서는 식초 발효 중 주요 유기산은 acetic acid라고 보고하였고, 이는 본 연구 결과와도 유사하였으나 함량에 따른 차이는 있는 것으로 나타났다. Seo 등(21)은 초산균 종류에 따라 각종 유기산의 함량에 차이가 나타난다

Table 3. Change of the organic acid contents during vinegar fermentation of Elaeagnus multiflora fruit

\begin{tabular}{ccccc}
\hline \multirow{2}{*}{$\begin{array}{c}\text { Contents } \\
(\mathrm{mg} / \mathrm{mL})\end{array}$} & 10 & 20 & 40 & 60 \\
\cline { 2 - 5 } & \multicolumn{4}{c}{ Fermentation time (day) } \\
\hline Oxalic acid & $0.15 \pm 0.01^{1)}$ & $0.16 \pm 0.02$ & $0.15 \pm 0.01$ & $0.26 \pm 0.03$ \\
Tartaric acid & $1.65 \pm 0.02$ & $0.76 \pm 0.02$ & $0.51 \pm 0.05$ & $0.93 \pm 0.05$ \\
Malic acid & $1.27 \pm 0.10$ & $1.48 \pm 0.09$ & $1.28 \pm 0.11$ & $1.51 \pm 0.10$ \\
Ascorbic acid & $1.38 \pm 0.08$ & $1.18 \pm 0.07$ & $0.94 \pm 0.06$ & $1.01 \pm 0.06$ \\
Lactic acid & $3.69 \pm 0.22$ & $4.43 \pm 0.27$ & $4.12 \pm 0.25$ & $4.92 \pm 0.30$ \\
Acetic acid & $2.64 \pm 0.16$ & $16.35 \pm 0.98$ & $18.31 \pm 1.10$ & $38.84 \pm 2.33$ \\
Citric acid & $0.41 \pm 0.02$ & $0.70 \pm 0.04$ & $0.89 \pm 0.05$ & $0.96 \pm 0.06$ \\
Succinic acid & $0.71 \pm 0.04$ & $1.51 \pm 0.09$ & $1.13 \pm 0.07$ & $2.25 \pm 0.14$ \\
Fumaric acid & $0.04 \pm 0.00$ & $0.05 \pm 0.00$ & $0.07 \pm 0.00$ & $0.05 \pm 0.00$ \\
Glutaric acid & $\mathrm{ND}{ }^{2)}$ & $\mathrm{ND}$ & $\mathrm{ND}$ & $\mathrm{ND}$ \\
Total & $11.94 \pm 0.60$ & $26.62 \pm 1.33$ & $27.4 \pm 1.37$ & $50.73 \pm 2.54$ \\
\hline
\end{tabular}

${ }^{12}$ All data are presented as the mean $\pm \mathrm{SD}$ of triplicate determinations.

${ }^{2} \mathrm{ND}$, not detected.
고 보고하였으며 이를 바탕으로 유기산 함량 변화의 차이는 원료 과실의 종류, 초산균의 종류 및 발효 방법 등에 따라 결과가 다르게 도출될 수 있다 판단된다.

\section{뜰보리수 열매 식초의 자연 발효 중 항산화 물질 함량 변화}

뜰보리수 열매 식초의 자연 발효 중 수용성 phenolics 및 flavonoids 함량 변화는 Table 4와 같았다. 수용성 phenolics 함량은 각각 $0.79 \mathrm{mg} / \mathrm{mL}$ (발효 10 일), $1.03 \mathrm{mg} / \mathrm{mL}$ (발효 20일), $1.18 \mathrm{mg} / \mathrm{mL}$ (발효 40일) 및 $1.22 \mathrm{mg} / \mathrm{mL}$ (발효 60 일)로 발효 과정 중 서서히 증가하였다. 수용성 flavonoids 함량은 각각 $0.12 \mathrm{mg} / \mathrm{mL}$ (발효 10 일), $0.13 \mathrm{mg} / \mathrm{mL}$ (발효 20 일), $0.13 \mathrm{mg} / \mathrm{mL}$ (발효 40일) 및 $0.14 \mathrm{mg} / \mathrm{mL}$ (발효 60일)로 발효 과정 중 크게 변화는 없는 것으로 나타났다(Table 4).

Table 4. Change of soluble phenolic and flavonoid contents during vinegar fermentation of Elaeagnus multiflora fruit

\begin{tabular}{ccccc}
\hline \multirow{2}{*}{ Contents $(\mathrm{mg} / \mathrm{mL})$} & \multicolumn{4}{c}{ Fermentation time (day) } \\
\cline { 2 - 5 } & 10 & 20 & 40 & 60 \\
\hline Soluble phenolics & $0.79 \pm 0.01^{1)}$ & $1.03 \pm 0.00$ & $1.18 \pm 0.02$ & $1.22 \pm 0.01$ \\
Soluble flavonoids & $0.12 \pm 0.00$ & $0.13 \pm 0.01$ & $0.13 \pm 0.01$ & $0.14 \pm 0.00$ \\
\hline
\end{tabular}

${ }^{1)}$ All data are presented as the mean \pm SD of triplicate determinations.

뜰보리수 열매 식초의 발효 기간별 flavonols 및 phenolic acids 함량 변화는 Table 5와 같았다. Flavonols 화합물 중 3종의 catechin gallocatechin gallate 및 catechin gallate는 발효 과정 중 검출되지 않았다. Epigallocatechin과 epicatechin 은 발효가 진행됨에 따라 조금씩 함량이 증가하였고, 발효 60 일째 각각 $24.84 \mathrm{mg} / \mathrm{mL}$ 및 $37.42 \mathrm{mg} / \mathrm{mL}$ 를 함유하고 있었 고, epigallocatechin gallate와 epicatechin gallate는 반대로 함량이 감소하여 각각 $24.53 \mathrm{mg} / \mathrm{mL}$ 및 $115.97 \mathrm{mg} / \mathrm{mL}$ 를 함유하고 있었다. 발효 전 기간에 걸쳐 주요 flavonols 화합 물은 epicatechin gallate이었으나 발효 과정 중 감소하는 결과를 나타내어 발효 60일째 총 flavonols 함량은 202.76 $\mathrm{mg} / \mathrm{mL}$ 를 함유하고 있었다(Table 5).

Phenolic acids 화합물은 11종 중 6종의 화합물(tannic acid, caffeic acid, chlorgenic acid, salicylic acid, sinapic acid 및 $\mathrm{t}$-cinnamic acid)이 검출되지 않았다. 한편 gallic acid, p-hydroxylbenzoic acid 및 p-coumaric acid는 발효 과정 중 조금씩 증가하였고 gallic acid가 가장 크게 증가하였다. 발 효 60 일째 각각 $95.07 \mathrm{mg} / \mathrm{mL}, 4.14 \mathrm{mg} / \mathrm{mL}$ 및 $3.43 \mathrm{mg} / \mathrm{mL}$ 를 함유하고 있었다. Vanillic acid는 발효 40일째 2. $88 \mathrm{mg} / \mathrm{mL}$ 가 검출되었고 이후에는 감소하는 경향을 나타내었다. 한 편 flavonols 함량과는 다르게 총 phenolic acids 함량은 발효 가 진행됨에 따라 조금씩 증가하였고 발효 60 일째 322.25 $\mathrm{mg} / \mathrm{mL}$ 를 함유하고 있었다(Table 5).

Flavonols 및 phenolic acids 등의 생리활성 화합물들은 자연계에 널리 존재를 하며 일반적으로 식용 가능한 식물에 
존재하고 항산화 활성과 같은 생리활성이 뛰어난 것으로 알려져 있다(5,22). Kim 등(23)은 보리수 열매주의 총 phenolics 함량을 측정한 결과 $0.37 \mathrm{mg} / \mathrm{mL}$ 를 함유한 것으로 보고하였으며, 이는 열매에 다량 함유되어 있으며 떫은맛 에 영향을 주고 항산화 활성과 밀접한 관련이 있다고 보고 하였다(24). 일반적으로 phenolics 화합물들은 분자 내 hydroxyl기가 각종 거대 분자와 결합하여 생리활성을 나타 낸다고 알려져 있다(25). 또한 본 연구에서 검출된 flavonols 중 catechin류와 phenolic acids 중 gallic acid의 경우에는 섭취하였을 시 항산화 활성이 뛰어난 것으로 보고되어있 고, Lee 등(5) 역시 뜰보수리 열매의 주요 화합물은 catechin 류와 gallic acid 등을 함유하고 있다고 보고하여 본 연구 결과와도 일치하였다. 한편 발효초기에는 catechin류 함량 과 탄닌류의 저 분자 phenolic acids 함량이 거의 유사하였으 나, 발효가 진행됨에 따라 catechin류 함량은 감소하였고 탄닌류는 증가하였다. 이는 발효가 진행됨에 따라 수용성
저 분자 탄닌류가 자연 발효액에 더 많이 용출된 것으로 판단되었다. 특히, 본 연구에서는 epigallocatechin gallate 및 epicatechin gallate 2 종이 발효 과정 중 점차 감소하였으 며, 이는 발효 미생물이 생성하는 esterase 효소 작용으로 ester 결합된 화합물들이 분해되고 이에 따라 gallic acid가 증가한 것으로 추정되었고다. Cho와 Joo(1) 및 Joo 등(26)은 과실주 발효 시 esterase 효소 작용에 의해 gallic acid가 증가 하는 것으로 보고하여 본 연구 결과와 유사하였다. 따라서 본 연구에서 생리활성 물질의 변화는 발효 원료 및 발효 과정 중 생성되는 산이나 미생물 유래 당 혹은 지방 가수분 해효소 등에 의해 결합형 polyphenol성 화합물이 유리형으 로 전환된 것으로 추정되어졌다.

\section{뜰보리수 열매 식초의 자연 발효 중 항산화 활성 변화}

뜰보리수 열매 식초의 자연 발효 중 항산화 활성(DPPH, $\mathrm{ABTS}$ 및 $\cdot \mathrm{OH})$ 을 측정한 결과는 Fig. 1 과 같았다. 3 종의

Table 5. Change of the phytochemical contents during vinegar fermentation of Elaeagnus multiflora fruit

\begin{tabular}{|c|c|c|c|c|}
\hline \multirow{2}{*}{ Contents $(\mu \mathrm{g} / \mathrm{mL})$} & \multicolumn{4}{|c|}{ Fermentation time (day) } \\
\hline & 10 & 20 & 40 & 60 \\
\hline \multicolumn{5}{|c|}{ Flavan-3-ol derivatives } \\
\hline Epigallocatechin & $19.22 \pm 1.15^{1)}$ & $19.75 \pm 1.19$ & $22.72 \pm 1.36$ & $24.84 \pm 1.49$ \\
\hline Catechin & $\mathrm{ND}^{2)}$ & ND & ND & ND \\
\hline Epicatechin & $33.72 \pm 2.02$ & $34.45 \pm 2.07$ & $35.84 \pm 2.15$ & $37.42 \pm 2.25$ \\
\hline Epigallocatechin gallate & $42.79 \pm 2.57$ & $37.75 \pm 2.27$ & $26.87 \pm 1.61$ & $24.53 \pm 1.47$ \\
\hline Gallocatechin gallate & ND & $\mathrm{ND}$ & $\mathrm{ND}$ & ND \\
\hline Epicatechin gallate & $168.10 \pm 10.09$ & $141.45 \pm 8.49$ & $121.97 \pm 7.32$ & $115.97 \pm 6.96$ \\
\hline Catechin gallate & ND & $\mathrm{ND}$ & $\mathrm{ND}$ & ND \\
\hline Total & $263.83 \pm 15.83$ & $233.4 \pm 14.00$ & $207.4 \pm 12.44$ & $202.76 \pm 12.17$ \\
\hline \multicolumn{5}{|c|}{ Phenolic acid derivatives } \\
\hline Gallic acid & $18.52 \pm 0.93$ & $45.11 \pm 2.26$ & $81.41 \pm 4.07$ & $95.07 \pm 4.75$ \\
\hline Protocatechuic acid & $8.93 \pm 0.45$ & $8.62 \pm 0.43$ & $9.10 \pm 0.46$ & $8.90 \pm 0.45$ \\
\hline Tannic acid & ND & ND & ND & ND \\
\hline$\rho$-Hydroxylbenzoic acid & $1.84 \pm 0.09$ & $2.78 \pm 0.14$ & $3.60 \pm 0.18$ & $4.14 \pm 0.21$ \\
\hline Vanillic acid & ND & ND & $2.88 \pm 0.14$ & $1.66 \pm 0.08$ \\
\hline Caffeic acid & ND & ND & $\mathrm{ND}$ & ND \\
\hline Chlorogenic acid & ND & ND & ND & ND \\
\hline Salicylic acid & ND & $\mathrm{ND}$ & ND & ND \\
\hline$\rho$-Coumraic acid & $2.74 \pm 0.14$ & $3.10 \pm 0.16$ & $3.20 \pm 0.16$ & $3.43 \pm 0.17$ \\
\hline Sinapic acid & ND & ND & ND & $0.68 \pm 0.03$ \\
\hline Ferulic acid & $\operatorname{Tr}^{3)}$ & $5.45 \pm 0.27$ & $5.76 \pm 0.29$ & $5.61 \pm 0.28$ \\
\hline t-Cinnamic acid & ND & ND & $\mathrm{ND}$ & ND \\
\hline Total & $32.03 \pm 1.60$ & $65.06 \pm 3.25$ & $105.95 \pm 5.30$ & $119.49 \pm 5.97$ \\
\hline Total $(1+2)$ & $295.86 \pm 14.79$ & $298.46 \pm 14.92$ & $313.35 \pm 15.67$ & $322.25 \pm 16.11$ \\
\hline
\end{tabular}

\footnotetext{
${ }^{1}$ All data are presented as the mean \pm SD of triplicate determinations. 
라디칼 소거활성은 발효 20 일째 급격히 증가하였고 이후에 도 지속적으로 증가하는 경향을 보였다.

$\mathrm{DPPH}$ 라디칼 소거활성은 발효 10 일째에는 $30.88 \%$ 의 다소 낮은 활성을 나타낸 반면 발효 20일째에는 크게 증가 하여 $63.14 \%$ 를 나타내었다. 발효 40 일째에는 약간 증가하 여 $68.89 \%$ 를 나타내었고 발효 60 일째에는 $71.35 \%$ 의 우수 한 DPPH 라디칼 소거활성을 보였다(Fig. 1A). ABTS 라디 칼 소거활성은 발효 기간에 따라 각각 $27.56 \%$ (발효 10 일), $62.18 \%$ (발효 20일), 76.12\%(발효 40일) 및 79.27\%(발효 60 일)로 $\mathrm{DPPH}$ 보다 약간 더 우수한 라디칼 소거활성을 보였다 (Fig. 1B). Hydroxyl(·OH) 라디칼 소거활성 역시 DPPH 및 $\mathrm{ABTS}$ 와 마찬가지로 발효 과정 중 꾸준히 증가하는 경향을 나타내었고 발효 60 일째 $68.72 \%$ 의 소거활성을 보였다

(Fig. 1C).
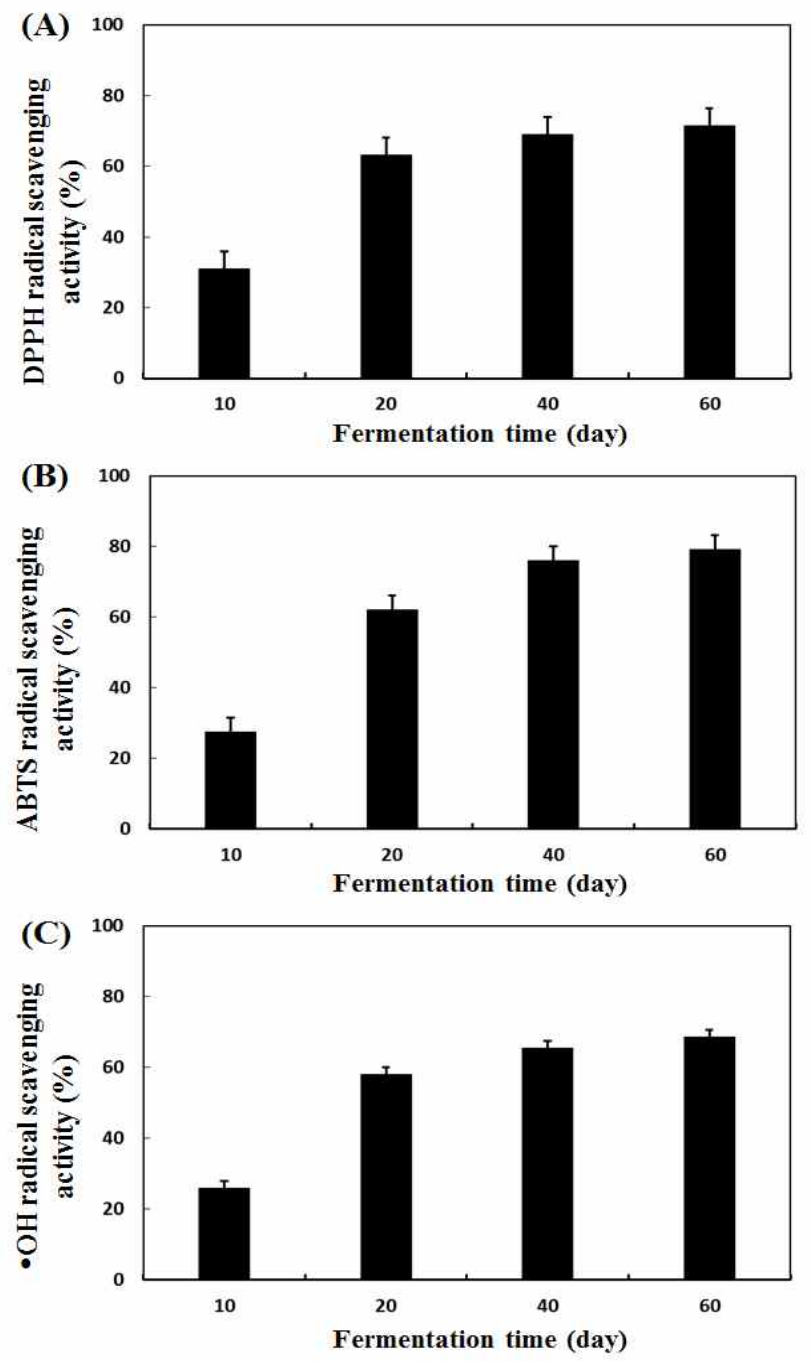

Fig. 1. Change of radical scavenging activity during vinegar fermentation of Elaeagnus multiflora fruit

A, DPPH radical scavenging activity; B, ABTS radical scavenging activity; and C, Hydroxyl $(\cdot \mathrm{OH})$ radical scavenging activity.

All data are presented as the mean \pm SD of triplicate determinations.
Kang 등(27)은 항산화 활성의 지표 물질은 phenolic acid 와 flavonoid 화합물이라 하였으며, phenolic 화합물의 농도 가 상승할수록 증가한다고 보고하였다(3). 이러한 연구 결 과로 볼 때 본 연구에서는 flavonols 중에서는 epicatechin gallate와 phenolic acids 중에서는 gallic acid의 영향을 받아 우수한 라디칼 소거활성을 나타낸 것으로 판단되었다. 이 러한 결과는 Hong 등(7)의 복분자 식초, Park 등(28)의 현미 배 식초, Verzalloni 등(29)의 발사믹 식초 연구에서 많은 양의 안토시아닌 및 phenolic 물질들이 항산화 활성 증가에 크게 영향을 미친다는 결과와 일치함을 알 수 있다.

\section{뜰보리수 열매 식초의 자연 발효 중 소화효소 저해활성 변화}

뜰보리수 열매 식초의 발효 기간별 탄수화물(a-glucosidase 및 a-amylase) 및 지방(pancreatic lipase) 분해효소의 저해활 성을 측정한 결과는 Fig. 2와 같았다. 탄수화물 및 지방 분해효소 저해활성은 발효 20 일째 급격히 증가하였고 이후 에도 지속적으로 증가하는 경향을 보였다.

a-Glucosidase 저해활성은 발효 10 일째 $5.77 \%$ 로 아주 낮 은 활성을 보였고 발효 20일째에는 조금 증가하여 $33.25 \%$ 를 나타내었다. 발효 40일째에는 약 $79 \%$ 를 나타내었고 60 일째에는 $85.42 \%$ 의 우수한 저해활성을 나타내었다(Fig. 2A). a-Amylase 저해활성은 $1.22 \%$ 로 발효 10 일째에 거의 활성을 보이지 않았으나 점차적으로 증가하여 발효 60일째 에는 $52.12 \%$ 의 우수한 저해활성을 보였다(Fig. 2B). Pancreatic lipase 저해 활성 역시 발효 10 일째에는 거의 없었고 발효 40 일째 $49.21 \%$ 를 나타내었고 발효 60 일째에는 $53.66 \%$ 의 지방분해 효소 저해활성을 나타내었다(Fig. 2C).

탄수화물을 섭취함으로써 a-amylase를 통해 이당류로 분 해되고 분해된 이당류는 a-glucosidase에 의해 단당류로 분 해되어 소장에 존재하는 융털을 통해 흡수되어 혈관으로 당이 이동하게 되며, 혈당이 증가된다. 탄수화물 분해효소 인 a-amylase 혹은 a-glucosidase를 억제시켜 분해되는 다당 류 혹은 이당류의 양을 감소시켜 흡수되는 양을 줄여 급격 한 혈당의 증가를 억제시켜 준다 $(15,30,31)$. Pancreatic lipase는 중성지방을 분해하는 효소로 작용한다. 그러나 이 현상이 지속될 경우 체중 증가와 더불어 당뇨, 동맹경화, 심혈관질환 등의 위험에 노출될 수 있으므로(32) 본 연구에 서는 지방분해 효소 저해활성을 측정하였다. 한편, 탄수화 물 분해효소 저해활성에 관여하는 물질은 polyphenol성 화 합물 중 flavonols 화합물로 알려져 있으며(33) 지방 분해효 소 저해활성 역시 polypehnol성 화합물에 유래된 결과들이 보고되어 있다(16). 따라서 본 결과에서 뜰보리수 열매 혹은 이로부터 발효된 식초에 함유된 flavonols 및 phenolic acids 화합물에 기인하여 탄수화물과 지방 분해효소 저해활성이 나타나는 것으로 추측되었다. 

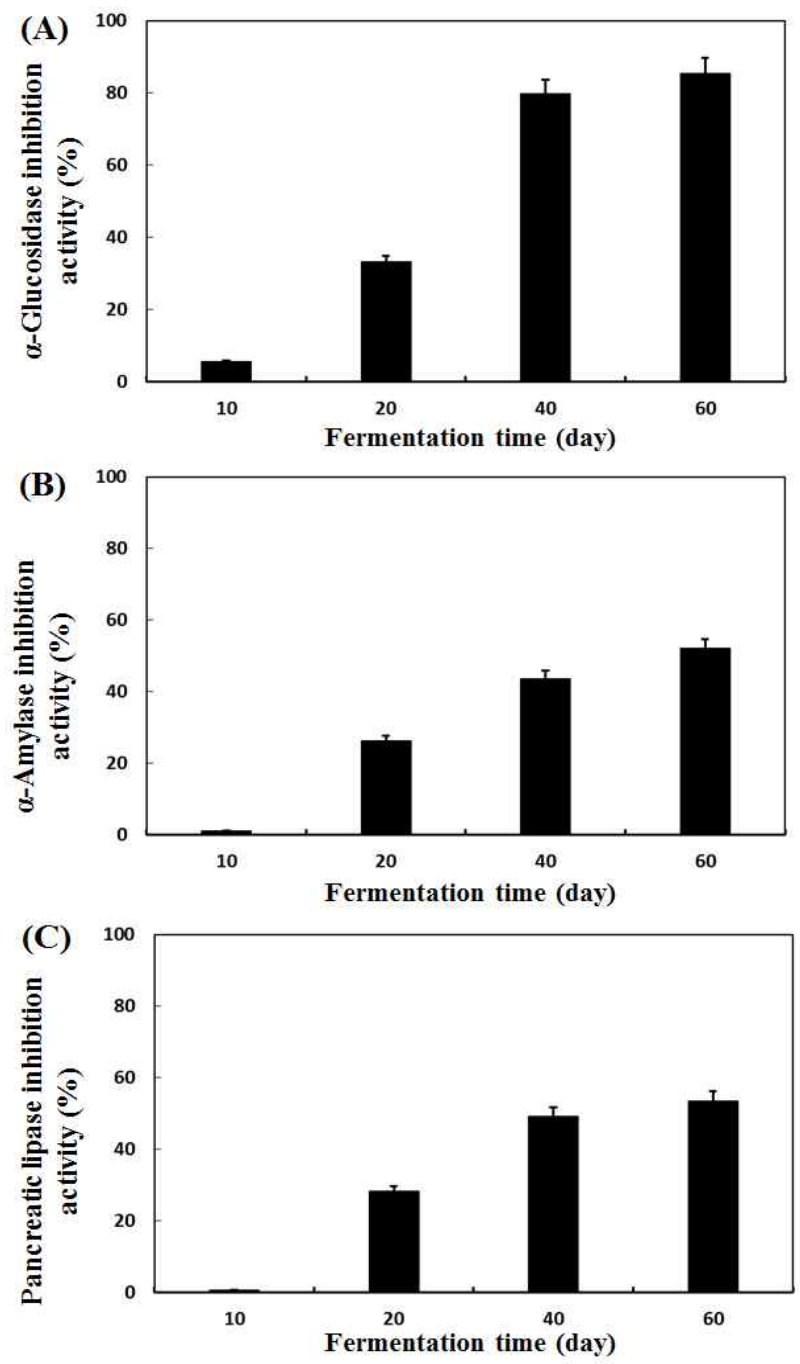

Fig. 2. Change of enzymatic inhibition activity during vinegar fermentation of Elaeagnus multiflora fruit

A, a-Glucosidase inhibition activity; B, a-Amylase inhibition activity; and C, Pancreatic lipase inhibition activity.

All data are presented as the mean $\pm \mathrm{SD}$ of triplicate determinations.

\section{요 약}

뜰보리수 열매 식초 발효 중 이화학적 특성, 생리활성 물질(flavonols과 phenolic acids) 및 생리활성 변화를 조사하 였다. 자연 발효 중 $\mathrm{pH}$ 와 환원당은 발효 초기 각각 3.55 와 $6.88 \mathrm{mg} / \mathrm{mL}$ 에서 3.34 와 $2.13 \mathrm{mg} / \mathrm{mL}$ 로 감소하였고, 반면에 산도는 $0.48 \%$ 에서 $5.48 \%$ 로 증가하였다. 알코올 함량은 20 일째까지 증가하여 $6.6 \%$ 로 최대치를 나타낸 후 감소하여 발효 종기 $2.0 \%$ 를 나타내었다. 초산균수는 발효 10 일째 $4.32 \log \mathrm{CFU} / \mathrm{mL}$ 에서 $5.4 \log \mathrm{CFU} / \mathrm{mL}$ 로 증가하였고, 효모 균수는 $3.23 \log \mathrm{CFU} / \mathrm{mL}$ 에서 $5.5 \log \mathrm{CFU} / \mathrm{mL}$ 로 증가하였 다. 뜰보리수 열매 식초의 주요 유기산은 초산, 젖산 및 사과산으로 각각 $38.84 \mathrm{mg} / \mathrm{mL}, 4.92 \mathrm{mg} / \mathrm{mL}$ 및 $1.51 \mathrm{mg} / \mathrm{mL}$
를 함유하고 있었다. 수용성 phenolics와 flavonoids 함량은 발효 중에 증가하여 발효 초기 각각 $0.79 \mathrm{mg} / \mathrm{mL}$ 과 0.12 $\mathrm{mg} / \mathrm{mL}$ 에서 $1.22 \mathrm{mg} / \mathrm{mL}$ 과 $0.14 \mathrm{mg} / \mathrm{mL}$ 로 증가하였다. Flavonols 화합물 중 epicatechin gallate는 발효 10 일째 168.1 $\mu \mathrm{g} / \mathrm{mL}$ 에서 $115.97 \mu \mathrm{g} / \mathrm{mL}$ 로 감소하였으나, phenolic acids 화합물 중 gallic acid는 $18.52 \mu \mathrm{g} / \mathrm{mL}$ 에서 $95.07 \mu \mathrm{gg} / \mathrm{mL}$ 로 증가하였다. 자연 발효 60 일째 $\mathrm{DPPH}$ 라디칼 소거활성은 $71.35 \%, \mathrm{ABTS}$ 라디칼 소거활성은 $79.27 \%$, hydroxyl 라디 칼 소거활성은 $68.72 \%$, a-glucosidase 저해활성은 $85.42 \%$, a-amylase 저해활성은 $52.12 \%$ 및 pancreatic lipase 저해활성 은 $53.66 \%$ 를 나타내었다.

\section{감사의 글}

이 논문은 2014년 국립경남과학기술대학교의 연구비 지 원에 의하여 연구되었습니다.

\section{References}

1. Cho KM, Joo OS (2014) Quality and antioxidant charactistics of Elaeagnus multiflora wine through the thermal processing of juice. J Food Preserv, 21, 206-214

2. Hong JY, Cha HS, Shin SR, Jeong YJ, Youn KS, Kim MH, Kim NW (2007) Optimization of manufacturing condition and physicochemical properties for mixing beverage added extract of Elaeagnus multiflora Thumb. fruits. Korean J Food Preserv, 14, 269-275

3. Youn KY, Hong JY, Nam HS, Moon YS, Shin SR (2007) Antioxidant activities and xanthine oxidase inhibitory effects of hot-water extracts from fruits of Elaeagnus multiflora Thumb. in maturity. J Korean Soc Food Sci Nutr, 36, 14-19

4. Kim NW, Joo EY, Kim SL (2003) Analysis on the components of the fruit of Elaeagnus multiflora Thumb. Korean J Food Preserv, 10, 534-539

5. Lee JH, Seo WT, Cho KM (2011) Dertermination of phytochemical contents and biological activity from the fruits of Elaeagnus multiflora. J Food Sci Nutr, 16, 29-36

6. Cho KM, Shin JH, Seo WT (2013) Production of Korean domestic wheat (Keumkangmil) vinegar with Acetobacter pasteurianıs A8. Korean J Food Sci Technol, 45, 252-256

7. Hong SM, Kang MJ, Lee JH, Jeong JH, Kwon SH, Seo KI (2012) Production of vinegar using Rubus coreanus and its antioxidant activities. Korean J Food Preserv, 19, 594-603 
8. Lee GD, Kim SK, Lee JM (2003) Optimization of the acetic acid fermentation condition for preparation of strawberry vinegar. J Korean Soc Food Sci Nutr, 32, 812-817

9. Woo SM, Kim OM, Choi IW, Kim YS, Choi HD, Jeong YJ (2007) Condition of acetic acid fermentation and effect of oligosaccharide addition on kiwi vinegar. Korean J Food Preserv, 14, 100-104

10. Jeong YJ, Seo JH, Park NY, Shin SR, Kim KS (1999) Changes in the components of persimmon vinegars by two stages fermentation ( I ). Korean J Food Preserv, 6, 228-232

11. Seo JH, Lee GD, Jeong YJ (2001) Optimization of the vinegar fermentation using concentrated apple juice. J Korean Soc Food Sci Nutr, 30, 460-465

12. Kim OM, Ha DJ, Jeong YJ (2003) Antibacterial activity of vinegars on Streptococcus mutans caused dental caries. Korean J Food Preserv, 10, 565-568

13. Miller GL (1959) Use of dinitrosalicylic acid reagent for the determination of reducing sugar. Anal Chem, 31, 426-428

14. Singleton VL, Rossi JA (1965) Colorimetry of total phenolics with phosphomolybdic-phosphotungstic acid reagents. Am J Enol Viti, 16, 144-158

15. Ahn MJ, Heung JY, Lee HY, Hwang CE, Jeong YS, Hong SY, Kwon OK, Kang SS, Kim HR, Park DS, Cho KM (2015) Effect of the enhanced biological activities and reduced bitter taste of bitter melon (Momordica charantia L.) by roasting. J Agric Life Sci, 49, 107-119

16. Park JS (2013) Effect on the inhibition of pancreatic lipase and lipid metabolism of Zanthoxylum piperitum extracts. Korean J Food Nutr, 26, 615-619

17. Park JH, Baek MR, Lee BH, Yon GH, Ryu SY, Kim YS, Park SU, Hong, KS (2009) a-Glucosidase and a -amylase inhibitory activity of compounds from roots extract of Pueraria thunbergiana. Korean J Medicinal Crop Sci, 17, 357-362

18. Lee MK, Choi SR, Lee J, Choi YH, Lee JH, Park KV, Kwon SH, Seo KI (2012) Quality characteristics and anti-diabetic effect of yacon vinegar. J Korean Soc Food Sci Nutr, 41, 79-86

19. Sim HJ, Seo WT, Choi MH, Kim KH, Shin JH, Kang MJ (2016) Quality characteristics of vinegar added with different levels of black garlic. Korean J Food Cook Sci, $32,16-26$

20. Yi MR, Hwang JH, Oh YS, Oh HJ, Lim SB (2014) Quality characteristics and antioxidant activity of immature Citrus unshiu vinegar. J Korean Soc Food Sci Nutr, 43, 250-257
21. Seo JH, Jeong YJ Kim JN, Woo CJ, Yoon SR, Kim TH (2001) Quality comparison of potato vinegars produced by various acetobacter bacteria. Korean $\mathbf{J}$ Postharvest Sci Technol, 8, 60-65

22. Miliauskas G, Venskutonis PR, Van Beek TA (2004) Screening of radical scavenging activity of some medicinal and aromatic plant extracts. Food Chem, 85, 231-237

23. Kim JY, Nam KS, Noh SK (2012) Cherry silverberry (Elaeagnus multiflora) wine mitigates the development of alcoholic fatty liver in rats. J Korean Soc Food Sci Nutr, 41, 57-64

24. Aoshima H, Tsunoue H, Koda H, Kiso Y (2004) Aging of whiskey increase 1.1-diphenyl-2-picrylhydrazyl radical scavenging activity. J Agric Food Chem, 52, 5240-5244

25. Husain SR, Cillard J, Cillard P (1987) Hydroxyl radical scavenging activity of flavonoids. Phytochemistry, 26, 2489-2491

26. Joo OS, Kang ST, Jeong CH, Lim JW, Prak YG, Cho KM (2011) Manufacturing of the enhances antioxidative wine using a ripe daebong persimmon (Dispyros kaki L). J Appl Biol Chem, 54, 126-134

27. Kang YH, Park YK, Lee GD (1996) The nitrite scavenging and electron donating ability of phenolic compounds. Korean J Food Sci Technol, 28, 232-239

28. Park EM, Lee HJ, Chung YK (2015) Quality characteristics and antioxidant activity of brown rice pear vinegar. J East Asian Soc Dietary Life, 25, 1041-1048

29. Verzalloni E, Tagliazucchi D, Conte A (2007) Relationship between the antioxidant properties and the phenolic and flavonoid content in traditional balsamic vinegar. Food Chem, 105, 564-571

30. Cha JY, Jin JS, Cho YS (2011) Biological activity of methanolic extract from Ganoderma lucidum, Momordica charantia, Fagopyrum tataricum, and their mixtures. J Life Sci 21, 1016-1024

31. Lo HY, Ho TY, Lin CJ, Li CC, Hsiang CY (2013) Momordica charantia and its novel polypeptide regulate glucose homeostasis in mice via binding to insulin receptor. J Agric Food Chem, 61, 2461-2468

32. Kim MS, Kim BY, Park CS, Yoon BD, Ahn SC, Oh WK, Ahn JS (2006) Inhibitory effect of Thujae orientalis semen extract on pancreatic lipase activity. J Life Sci, 16, 328-332

33. Kim JE, Joo SI, Seo JH, Lee SP (2009) Antioxidant and a-glucosidase inhibitory effect of tartary buckwheat extract obtained by the treatment of different solvent and enzymes. Korean J Soc Food Sci Nutr, 38, 989-995 